\title{
PELATIHAN DIGITAL MARKETING UNTUK MENINGKATKAN POTENSI WISATA KAMPUNG COKLAT MAJAPAHIT DI KECAMATAN DLANGGU KOTA MOJOKERTO
}

\author{
Tegowati $^{*}$, In'am Widiarma ${ }^{2}$, Yayah Atmajawati ${ }^{3}$ \\ ${ }^{1}$ Program Studi Manajemen, Sekolah Tinggi Ilmu Ekonomi Indonesia (STIESIA) Surabaya \\ *Email: tegowati@stiesia.ac.id
}

\begin{abstract}
Informasi Artikel
Abstrak

Kata kunci:

Wisata Coklat

Majapahit, Wisata Desa

BMJ Mojokerto,

Marketing Online

Diterima: 20-05-2021

Disetujui: 02-07-2021

Dipubikasikan: 16-07-

2021

Kakao adalah salah satu komoditas andalan kabupaten Mojokerto dan telah dikembangkan pada tahun 2010 di 12 kecamatan dan menghasilkan banyak produksi kakao dengan menjadikan wilayah kecamatan Dlanggu sebagai sentra pengembangan. Dalam pengembangan kakao, petani membutuhkan pembiayaan, peningkatan pengetahuan terkait pencegahan hama tanaman kakao, pengemasan produk dan marketing online. Maka Otoritas Jasa Keuangan (OJK) bersama dengan Dinas Perkebunan Provinsi Jatim \& BPR Jatim yang tergabung dalam Tim Percepatan Akses Keuangan Daerah Provinsi Jatim (TPAKD Jatim) menyelenggarakan "Business Matching Percepatan Akses Keuangan serta Pelatihan, Literasi dan Inklusi (PETIK) Keuangan" kepada 100 Petani Kakao di Mojokerto untuk meningkatkan kuantitas produksi kakao melalui pemberian fasilitas kredit bagi kelompok petani kakao \& meningkatkan kualitas kakao melalui pelatihan penanganan hama kakao, pengemasan produk dan marketing online. PKM ini (merupakan bagian dari acara yang diselenggarakan OJK dan TPAKD Jatim bertujuan untuk memberikan pengetahuan marketing online bagi petani kakao Mojokerto. Metode kegiatan pengabdian ini dilakukan dengan cara memberikan pelatihan tentang marketing online. Dengan pelatihan marketing online petani kakao telah memahami manfaat dan cara mengaplikasikan marketing online dengan baik..
\end{abstract}

\section{Keywords :}

Majapahit Chocolate

Tour, BMJ Mojokerto

Village Tour, Online

Marketing

\footnotetext{
Abstract

Cocoa is one of Mojokerto regency's mainstay commodities and has been developed in 2010 in 12 sub-districts and making the Dlanggu sub-district a development center. In developing cocoa, farmers need financing, increased knowledge related to cocoa plant pest prevention, product packaging and online marketing. So the Financial Services Authority (OJK) together the East Java Provincial Plantation Service \& East Java BPR who are members of the East Java Province Regional Financial Access Acceleration Team (East Java TPAKD) held a "Business Matching Acceleration of Financial Access and Training, Financial Literacy and Inclusion (PETIK)" to 100 Cocoa farmers in Mojokerto to increase the quantity of cocoa production through providing credit facilities for cocoa farmer groups \& improving
} 
cocoa quality through training in cocoa pest management, product packaging and online marketing. This PKM (which is part of an event organized by the TPAKD East Java aims to provide online marketing knowledge for Mojokerto cocoa farmers. With online marketing training, cocoa farmers have understood the benefits and how to properly apply online marketing.

\section{PENDAHULUAN}

Kakao adalah salah satu komoditas andalan kabupaten Mojokerto baik kualitas maupun kuantitas, dan telah mendapatkan perhatian dari pemerintah daerah. Potensi kakao di kota Mojokerto ini memang masih relatif baru, sehingga masih banyak dilakukan pengembangan baik dari segi tempat, pembibitan, pengelolaan hasil tanaman kakao, dan akses jalan menuju tempat wisata kakao. Untuk potensi marketing online juga belum maksimal dan harus terus dikembangkan karena saat ini berbagai informasi banyak diakses melalui online. Akses informasi melalui online baik situs web maupun aplikasi sosial media lebih disukai oleh para wisatawan karena lebih praktis dan informasi yang diperoleh juga relatif lebih lengkap. Implementasi pariwisata digital adalah cara untuk memenuhi permintaan tren pariwisata di Indonesia (Nagari \& Pangestuti, 2019). Desa wisata yang sedang dikembangkan memerlukan strategi komunikasi pemasaran digital dengan tujuan untuk meningkatkan jumlah kunjungan wisata secara efektif dan efisien (Kurnianti, 2018).

Dengan adanya respon yang sangat baik dari masyarakat, wisata kampung coklat Majapahit beserta pabrik coklat yang dimilikinya diharapkan bisa meningkatkan ekonomi petani kakao di Mojokerto, meskipun saat ini masih dominan wisatawan domestik. Pertumbuhan dan perkembangan kampung coklat membawa dampak yang sangat signifikan bagi kemajuan lingkungan dan daerah, baik secara sosial maupun ekonomi (Siswati \& Andari, 2019). Untuk destinasi wisata pedesaan lebih dominan wisatawan domestik (Hall, Kirkpatrick, \& Mitchell, 2005; Long \& Edgell, 1997 dalam Suryawardani, 2020). Kriteria desa wisata meliputi daya tarik, aksesibilitas, fasilitas umum dan fasilitas wisata, pemberdayaan masyarakat, dan pemasaran atau promosi (Komariah dkk, 2018).

Perkembangan kakao di kota Mojokerto ini dimulai pada tahun 2008 yang ditanam di tiga kecamatan yakni Pacet, Trawas dan Gondang. Kemudian di tahun 2010, kakao dikembangkan lagi dan menghasilkan nilai produksi yang lebih tinggi. Lokasi pengembangannya berada di 12 kecamatan yakni Trowulan, Trawas, Jatirejo, Gondang, Bangsal, Pungging, Kemlagi, Jetis, Sooko, Mojosari, Dawarblandong, dan Dlanggu sebagai sentra pengembangan. Hingga akhirnya pada tahun 2018, berdiri pabrik coklat yang mengolah hasil panen dari petani kakao jenis unggul. Di pabrik coklat ini pengunjung dapat melihat proses produksi coklat sekaligus menikmati olahan coklat segar baik batangan maupun serbuk yang langsung dikemas dalam 35 jenis olahan dengan label Coklat Majapahit dan tersedia di galery coklat dimana ada beberapa pohon coklat yang rindang disekitarnya. Harga jualnya cukup murah untuk oleh-oleh dan kualitas yang tidak kalah dengan coklat impor. Hal 
yang berperan penting pada strategi memasarkan industri coklat dalam jangka waktu lama adalah konteks historis dan sejarah bisnis (Ramli, 2017).

Destinasi kebun coklat / wisata Desa BMJ Mojopahit merupakan wisata terpadu kebun coklat. Disebut wisata terpadu karena wisata ini dilengkapi dengan berbagai fasilitas antara lain kolam renang, wahana permainan dan fasilitas edukasi. Fasilitas edukasi yang disediakan yakni belajar budidaya penanaman pohon coklat mulai dari pembibitan, penanaman, perawatan hingga proses pengolahan coklat. Pengunjung juga bisa melihat langsung ribuan pohon kakao yang telah berbuah sambil berfoto. Melalui wisata edukasi kampung coklat, secara tidak langsung gapoktan merangsang tumbuhnya partisipasi masyarakat sekitar untuk mengembangkan berbagai peluang usaha serta memanfaatkan potensi yang ada (Basyir dan Jannah, 2017).

Melihat dari beberapa fakta dilapangan, yakni: a) potensi kakao Mojokerto yang begitu besar dan patut untuk dikembangkan; b) meningkatnya permintaan coklat untuk pasar domestik dan semakin tingginya permintaan ekspor kakao; c) kebutuhan peningkatan kualitas kakao melalui pemberian pelatihan terkait penanganan hama kakao, pengemasan produk dan marketing online, maka Otoritas Jasa Keuangan (OJK) bersama dengan Dinas Perkebunan Provinsi Jawa Timur, BPR Jawa Timur yang tergabung dalam Tim Percepatan Akses Keuangan Daerah Provinsi Jawa Timur (TPAKD Jatim) menyelenggarakan "Business Matching Percepatan Akses Keuangan serta Pelatihan, Literasi dan Inklusi (PETIK) Keuangan” kepada 100 Petani Kakao di Mojokerto, Jawa Timur untuk meningkatkan kuantitas produksi kakao melalui pemberian fasilitas kredit bagi kelompok petani kakao dan peningkatan kualitas kakao melalui pemberian pelatihan terkait penanganan hama kakao, pengemasan produk dan marketing online. PkM ini (merupakan bagian dari penyelenggaraan acara Business Matching tersebut), bertujuan untuk memberikan pengetahuan tentang marketing online kepada petani kakao di Mojokerto, Jawa Timur. Marketing onlinel pemasaran media sosial merupakan suatu jenis model pemasaran internet untuk mencapai tujuan pemasaran dengan berpartisipasi dalam lingkup jaringan media sosial (Maoyan, 2014).

Memahami marketing online dan mampu melaksanakan pemasaran melalui online bagi destinasi wisata sangat penting, karena saat ini semua informasi (termasuk informasi tentang destinasi wisata) banyak di upload di media sosial sehingga para wisatawanpun mencari review melalui online. Untuk itulah dilaksanakan pengabdian kepada masyarakat ini melalui pelatihan marketing online dengan tujuan memaksimalkan pemasaran dan potensi wisata kampung coklat Majapahit di Mojokerto. Manfaat marketing online / digital marketing antara lain: a) meningkatkan promosi wisata pada generasi Y dan Z (Warmayana, 2018); b) mempengaruhi minat wisatawan untuk berkunjung (Hasan \& Hatibie, 2014; Elia dan Sunarti, 2018; Kurniawan, 2020); c) menciptakan awareness bagi target marketnya (Umami, 2015; Atiko, dkk; 2016; Dedeoğlu et all., 2020); d) kreatif dengan low budget dan terbukti mampu meningkatkan volume penjualan produk (Harinie dkk. 2020); e) penyebaran 
informasi objek dan destinasi wisata cepat menyebar luas tanpa batas ruang dan waktu (Sihombing \& Hariyanto, 2019; Pradiatiningtyas, 2014); f) meningkatkan citra merek (Pedrosa et all., 2020); g) menarik lebih banyak pelanggan potensial (Khuong and Huong, 2016); h) e-tourism memudahkan berwisata dengan system otomatis dan adanya multi bahasa (Bessie, 2019). Begitu banyak manfaat marketing online, sehingga pelatihan marketing online ini sangat penting untuk dilakukan.

\section{METODE}

Bentuk kegiatan pengabdian ini dilakukan dengan cara memberikan pelatihan tentang marketing online bagi petani kakao Mojokerto. Adapun rincian kegiatan yang telah dilaksanakan yaitu sebagai berikut:

a. Survey lokasi desa Randugenengan, Kecamatan Dlanggu, kota Mojokerto Jawa Timur.

b. Mengidentifikasi permasalahan yang dihadapi petani kakao, dengan cara melihat fenomena sosial ekonomi di Mojokerto serta melalukan wawancara kepada petani kakao.

c. Melakukan pelatihan sesuai permasalahan yang dihadapi oleh petani kakao yaitu pelatihan marketing online guna meningkatkan potensi wisata coklat Majapahit di kecamatan Dlanggu kota Mojokerto Jawa Timur.

d. Pada kegiatan monev yang telah dilakukan, hasil yang diperoleh diantaranya adalah beberapa produk yang dihasilkan oleh petani kakao telah mencantumkan identitas produk pada label kemasan sesuai saran yang telah diberikan pada waktu pelatihan (saat pelatihan belum dicantumkan identitas produk).

\section{HASIL DAN PEMBAHASAN}

Kegiatan pengabdian kepada masyarakat merupakan salah satu bagian dari Tridharma Perguruan Tinggi yang harus dilakukan setiap dosen kepada masyarakat dengan tujuan membantu kelompok masyarakat tertentu dalam menyelesaikan permasalahan-permasalahan yang sedang dialami. Kegiatan pengabdian kepada masyarakat ini dilaksanakan pada hari Jumat tanggal 01 November 2019 pukul 07.30-11.00 WIB. Tempat kegiatan pengabdian berlangsung di desa wisata BMJ Kelurahan Randugenengan Kecamatan Dlanggu Kota Mojokerto dan diikuti oleh 100 peserta yang merupakan gabungan kelompok petani Kakao Kota Mojokerto.
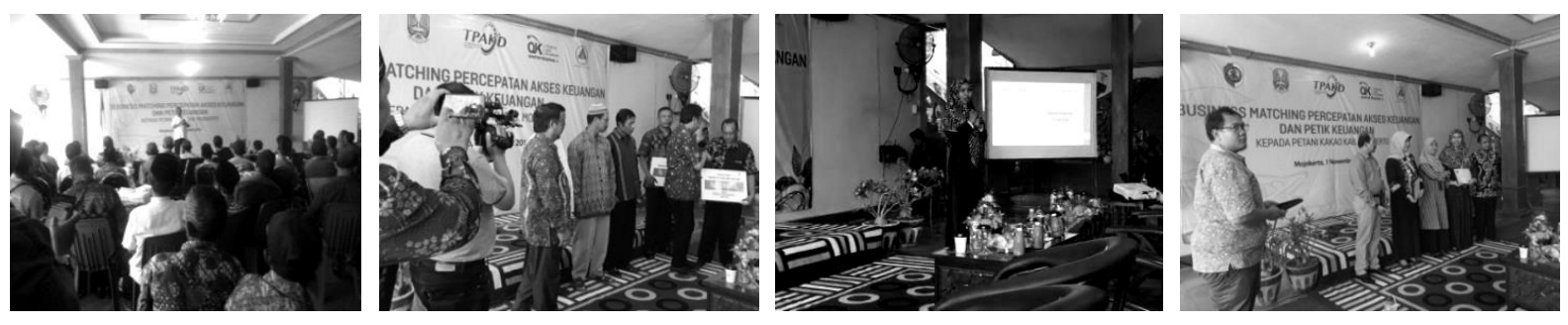

Gambar: Foto Rangkaian Kegiatan 
Karena kegiatan pengabdian ini merupakan bagian dari acara "Business Matching Percepatan Akses Keuangan serta Pelatihan, Literasi dan Inklusi (PETIK) Keuangan" yang dilakukan oleh TPAKD Jatim, maka ada acara-acara lain yang mendahului sebelum acara pelatihan marketing online. Adapun acara yang mendahului / rangkaian acara pelaksanaan kegiatan pengabdian kepada masyarakat di Desa Wisata BMJ kelurahan Randugenengan kecamatan Dlanggu kota Mojokerto pada hari Jumat, 01 November 2019 sebagai berikut: registrasi peserta \& pembukaan; sambutan ketua Gapoktan Mulyo Jati; sambutan OJK KR 4 Jawa Timur; sambutan bupati Mojokerto; penyerahan simbolis pencairan kredit; penandatanganan MoU pemasaran antara gapoktan mulyo jati dan pelaku usaha; produk \& layanan Perbankan (Hulu-Hilir \& PKPJ) oleh BPR Jatim, dan penyuluhan pencegahan hama tanaman kakao. Setelah penyuluhan pencegahan hama tanaman kakao oleh Dinas Perkebunan Jawa Timur, barulah pelatihan marketing online dan acara selanjutnya yaitu pelatihan pengemasan produk kemudian tanya jawab dan penutup.

Dalam pelatihan marketing online disampaikan cara membuat promosi yang menarik melalui marketing online dan keuntungan-keuntungan yang didapatkan jika menguasai marketing online. Diharapkan pelatihan marketing online ini dapat dimanfaatkan dengan baik sehingga meningkatkan potensi wisata coklat Majapahit. Kemudian dalam program Petik Keuangan, diharapkan tidak ada lagi petani yang menjual produknya sebelum panen dan bisa mendapatkan harga yang maksimal dari olahan hasil panen kakao. Petani kakao supaya lebih memperhatikan deal sistem jual beli kakao sebelum panen tiba, karena harga kakao yang dipesan untuk dibeli sebelum panen, dengan harga panen standar akan berbeda drastis. Pada kegiatan ini BPR Jatim juga melakukan pencairan kredit modal usaha kepada Gapoktan Mulyo Tani untuk melancarkan perkembangan usaha kakao.

Hasil dari kegiatan pelatihan marketing online yang sudah dilakukan, petani kakao menjadi paham pentingnya mempunyai jalur pemasaran melalui online dan mengetahui cara pemasaran online yang baik. Selain itu, pada produk yang dihasilkan telah mencantumkan identitas produk pada label kemasan (seperti mencantumkan nomer whatsapp dan nama akun media sosial). Pencantuman ini penting sebab wisatawan yang telah membeli produk (terutama wisatawan luar kota) akan lebih mudah dalam melacak produk sehingga mudah jika ingin membeli kembali.

\section{KESIMPULAN}

Pelatihan marketing online di desa wisata coklat Majapahit ini sangat tepat karena beragam manfaat marketing online dan permintaan tren pariwisata di Indonesia dalam penyajian akses informasi melalui online. Implementasi aplikasi e-commerce dalam bentuk pemasaran digital untuk desa wisata coklat sangat diperlukan disamping sebagai media promosi wisata, pemasaran digital/ marketing online juga memiliki banyak manfaat antara lain: meningkatkan jumlah pengunjung, menciptakan brand awareness bagi target marketnya, meningkatkan citra merek, lebih kreatif dengan low budget, penyebaran informasi objek dan destinasi wisata cepat menyebar luas, memudahkan 
wisatawan dengan informasi yang disajikan dan juga adanya multi bahasa. Pemasaran online yang baik dan terintegrasi juga dapat menaikkan pendapatan daerah (ditentukan oleh kelengkapan menu atau informasi yang disajikan dalam aplikasi online). Kegiatan pelatihan marketing online yang sudah dilakukan memberikan dampak positif yakni petani kakao menjadi paham pentingnya mempunyai jalur pemasaran melalui online dan mengetahui cara pemasaran online yang baik. Produk yang sebelumnya tidak mencantumkan identitas produk pada kemasan juga telah telah mencantumkan identitas produk pada label kemasan, sehingga memudahkan wisatawan yang ingin membeli kembali.

\section{UCAPAN TERIMAKASIH}

Kegiatan PkM ini dapat berjalan dengan lancar karena peran serta dan dukungan dari beberapa pihak. Kami menyampaikan terima kasih yang sebesar-besarnya kepada: OJK KR 4 Jawa Timur, yang telah bekerjasama dengan TPAKD Jatim dalam menyelenggarakan acara Business Matching Perluasan Akses Keuangan dan PETIK Keuangan Kepada Petani Kakao kota Mojokerto Jawa Timur.

\section{DAFTAR PUSTAKA}

Atiko, G., Ratih. H.S., Sudrajat, Kharisma, N. 2016. Analisis strategi promosi pariwisata melalui media sosial oleh kementerian pariwisata RI (Studi deskriptif pada akun instagram @indtravel). Jurnal Sosioteknologi, 15(3), 378-389. https://doi.org/10.5614/sostek.2016.15.3.6

Basyir, M.N., dan Jannah. R. 2017. Strategi penguatan usaha ekonomi petani kakao oleh gapoktan guyub santoso di desa plosorejo kecamatan kademangan kabupaten blitar (the economic prosperity strengthening strategy of cocoa farmers by gapoktan in the village of plosorejo, kademangan subdistrict, district of blitar). E-SOSPOL, 4(2), 115-120. https://jurnal.unej.ac.id/index.php/E-SOS/issue/view/785

Bessie, J.L.D. 2019. Implementasi e-commerce dalam industry pariwisata. Journal of management (SME's), 8(1), 45-62. https://doi.org/10.35508/jom.v8i1.1409

Dedeoğlu, B.B., Niekerk, M.V., Küçïkergin, K.G., De Martino, M., \& Okumuş, F. 2020. Effect of social media sharing on destination brand awareness and destination quality. Journal of Vacation Marketing, 26(1), 33-56. https://doi.org/10.1177/1356766719858644

Elia, F.N., dan Sunarti. 2018. Pengaruh bauran promosi terhadap keputusan kunjungan dan kepuasan pengunjung (survei pada pengunjung wisata kampung coklat kabupaten blitar). Jurnal $\begin{array}{llll}\text { Administrasi Bisnis } & \text { (JAB), 61(4), }\end{array}$ http://administrasibisnis.studentjournal.ub.ac.id/index.php/jab/article/view/2621/0

Harinie, L.T., Juma'eh, A., Hukom. 2020. Pendampingan dalam memasarkan produk hasil usaha ukm melalui penggunaan media sosial di kabupaten gunung mas kalimantan tengah. ENGAGEMENT, $\begin{array}{llll}\text { Jurnal } & \text { Pengabdian } & \text { Kepada }\end{array}$ https://doi.org/10.29062/engagement.v4i1.179

Hasan, A. \& Hatibie, I.K. 2014. Pengaruh elektronikal marketing terhadap minat wisatawan berkunjung ke pulau saronde. Jurnal Media Wisata, 12(2), 162-171. https://doi.org/10.36276/mws.v12i2.89

Khuong, M.N. \& Huong, T.T. 2016. The influence of social media marketing on vietnamese traveller's purchase intention in tourism industry in ho chi minh city. Journal of Economics, Business and Management, 4(4), 280-285. http://doi.org/10.18178/joebm.2016.4.4.404 
Komariah, N., Encang S., Pawit, M. Y. 2018. Pengembangan desa wisata berbasis kearifan lokal. Jurnal Pariwisata Pesona, 03(2), 158-174. http://doi.org/10.26905/jpp.v3i2.2340

Kurnianti, A.W. 2018. Strategi komunikasi pemasaran digital sebagai penggerak desa wisata kabupaten wonosobo provinsi jawa tengah. JURKOM, Jurnal Riset Komunikasi, 1 (1), 180-190. https://doi.org/10.24329/jurkom.v1i1.24

Kurniawan, A.R. 2020. Tantangan pengembangan pariwisata berbasis masyarakat pada era digital di Indonesia. TORNANE, Journal of sustainable tourism research, 3(1), 1-10. https://doi.org/10.24198/tornare.v2i2.25418

Maoyan, Z.S. 2014. Consumer purchase intention research based on social media marketing. International Journal of Business and Social Science. 5(10), 92-97. https://docplayer.net/7137108-Consumer-purchase-intention-research-based-on-social-mediamarketing.html

Nagari, M.P \& Pangestuti, E. 2019. Peran digital tourism dalam pengembangan kampung wisata Jodipan. JAB, Jurnal Administrasi Bisnis, 74(1),48-54. http://administrasibisnis.studentjournal.ub.ac.id/index.php/jab/article/view/2944

Pedrosa, C.D.L.H., Celis, E.M., Sánchez, P.P.I., \& Maldonado, C.J. 2020. Importance of social media in the image formation of tourist destinations from the stakeholders' perspective. Sustainability, 12, 4092, 1-27. https://ideas.repec.org/a/gam/jsusta/v12y2020i10p4092-d359211.html

Pradiatiningtyas, D. 2014. Pemasaran online melalui e-tourism, bauran pemasaran jasa pariwisata dan pemosisian untuk promosi pariwisata daerah di Indonesia . Khasanah Ilmu, 5(2), 77-87. https://doi.org/10.31294/khi.v5i2.479

Ramli, S. N. 2017. A Review of marketing strategies from the european chocolate industry. Journal of Global Entrepreneurship Research, 7(10),1-17. http://doi.org/ 10.1186/s40497-017-0068-0

Sihombing, D.A \& Hariyanto, O. I. B. 2019. Digital pemasaran pariwisata dan pendekatan soft skill di destinasi wisata. Jurnal ALTASIA, 1(2), 47-52. http://dx.doi.org/10.37253/altasia.v1i2.464

Siswati, E., dan Andari, B. 2019. "Confuse effect" dan "wow effect": strategi branding wisata edukasi $\begin{array}{llll}\text { kampung } \quad \text { Widya } & \text { Komunika, }\end{array}$ https://www.researchgate.net/publication/337783781_CONFUSE_EFFECT_DAN_WOW_EFF ECT_STRATEGI_BRANDING_WISATA_EDUKASI_KAMPUNG_COKLAT

Suryawardani, I.G.A.O., Wiranatha, A.S., Purbanto, I.G.R., \& Nitivattananon, V. 2020. Identification tourism products and services provided at the rural tourism destinations in Bali. International Journal of Economics and Financial Issues, 1(1), 65-85. http://arfjournals.com/abstract/95951_5.pdf

Umami, Z. 2015. Social strategi pada media sosial untuk promosi pariwisata daerah intimewa Yogyakarta. Jurnal Interaksi, 4(2) 195-201. https://doi.org/10.14710/interaksi.4.2.195-201

Warmayana, I.G.A.K. 2018. Pemanfaatan digital marketing dalam promosi pariwisata pada era industri 4.0. Jurnal Pariwisata Budaya, 3(2), 81-92. http://dx.doi.org/10.25078/pba.v3i2.649 